\title{
Off-Grid Photovoltaic System Design for Haiti School Project
}

\author{
Wentao Feng, Ziya M. Slameh \\ Department of Electrical Engineering, University of Massachusetts Lowell, Lowell, USA \\ Email: ziyad salameh@uml.edu
}

Received 20 September 2014; revised 30 October 2014; accepted 25 November 2014

Copyright (C) 2014 by authors and Scientific Research Publishing Inc.

This work is licensed under the Creative Commons Attribution International License (CC BY). http://creativecommons.org/licenses/by/4.0/

c) (†) Open Access

\begin{abstract}
In this paper a Photovoltaic (PV) system was designed for the Port-Margot School Solar Project in Haiti. This off-grid system consists of PV panels, inverter, battery storage and other components such as fuses, dc/ac disconnects and transformers [1]. Sizing the PV to fit on the roof was determined. The battery storage and inverter were chosen to be installed in the school building. The expected energy production was compared with data file from NASA website. The KW PV system was chosen to be the most effective and demonstrating renewable technologies and reducing the electrical load of the school.
\end{abstract}

\section{Keywords}

Haiti, Photovoltaic, Battery, Controller, Inverter, Layout

\section{Introduction}

This project is led by the Ministries of Aides International Organization, and its partners United Solar Associates, LLC, Solar World Co. will deliver donations at the most appropriate facility. University of Massachusetts Lowell's Renewable Energy Department is implementing the solar solution.

Solar electricity will allow for much improved cooling and ventilation in the offices and classrooms. Given the tropical temperatures averaging mid to high 90 degrees Fahrenheit, this is a problem in that overhead fans are inoperable due to intermittent electricity. As a result, the learning environment is adversely impacted with student concentration levels reduced. Also, the steady flow of electricity will provide power to the administrative offices and improve productivity with peripherals such as computers, copiers, printers, etc. Additionally, students and local residents will benefit form use of the same devices in the computer learning center.

According to the client's requirement, there are 6 perspectives in PV system model selection: Data collection, Electric appliance load calculation, Battery packs selection, PV array selection, Spacing between rows and Con- 
troller and Inverter selection.

\section{Methotology [2]}

The school located in Port-margot where is not far from cap-haitien. The following is the school's geographic location which shows in Figure 1. and the roof structure form the top view is shows in Figure 2. Grid Location: 19 degrees 45' North, 72 degrees 26' West.

Measurements: 21.85 meters (71.69 feet) in length.

The front is 5.65 meters (18.54 feet) in width.

The back is 4.8 meters ( 15.74 feet) in width.

Step 1. Data collection [3]

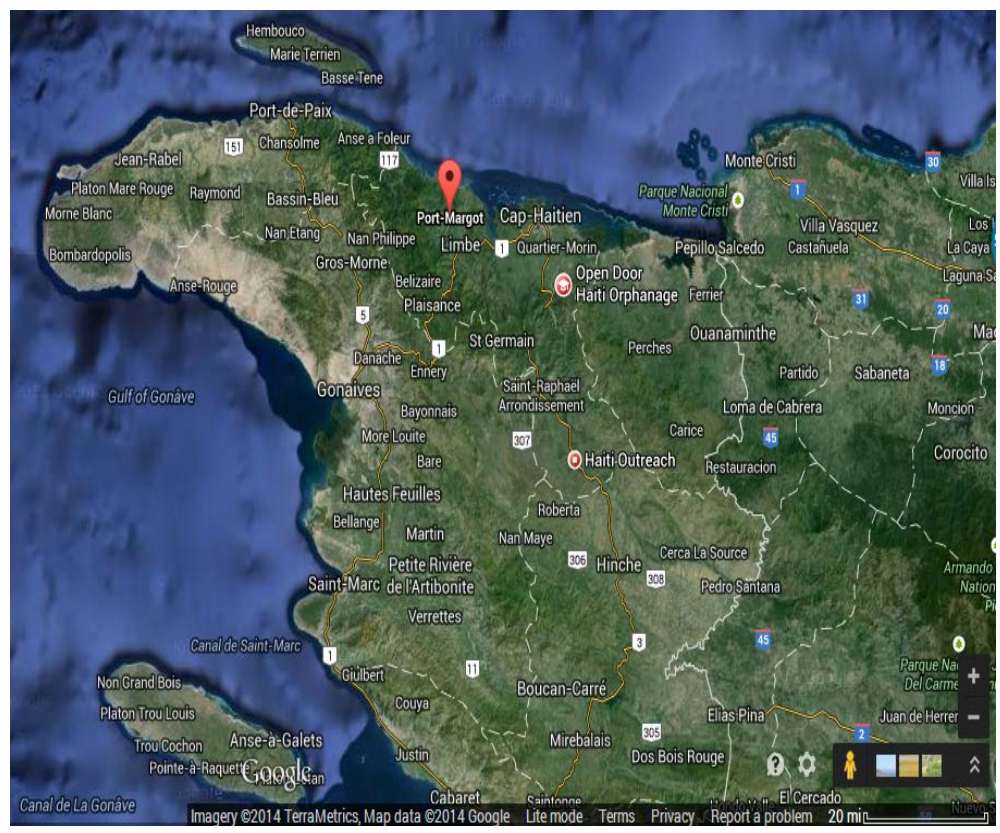

Figure 1. Geographic location [13].

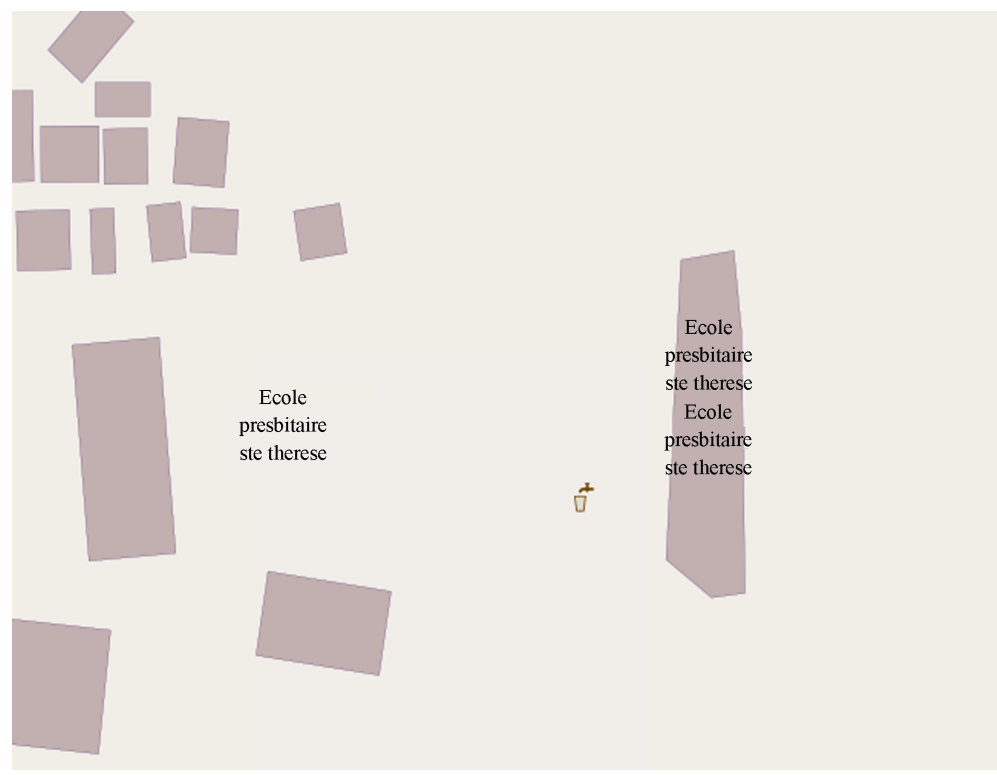

Figure 2. Top view [12]. 
Step 2. Load Calculation [4]

Illumination (Lux) $=$ light output lumen $\times$ lights number $\times 0.563 /$ Area $\left(\mathrm{m}^{2}\right)$

$500=3000 \times$ number $\times 0.563 /(3 \times 2.5)$

Number $=2.22 \approx 3$

So we choose 3 for each classroom in the calculation after.

According to the Load Evaluation Table present in Table 1, the Total electrical power is 10,241 w, and the daily electricity consumption is $29.92 \mathrm{~kW} \cdot \mathrm{h}$, on the basis of simultaneously utilized rate we get the total power is $6144.6 \mathrm{w}$, and daily electricity consumption is $17.95 \mathrm{~kW} \cdot \mathrm{h}$.

Step 3. Battery Sizing [5]

Equivalent Autonomy Days (No-Sun or Black Days)

Take Autonomy days for 3, and DOD for $80 \%$

Average Discharge Rate calculate formula:

Weighted average load work time:

$$
\sum \text { Energy } / \sum \text { Power }=17950 / 6144.6 \mathrm{w}=2.92 \mathrm{~h}
$$

Average Discharge Rate $(\mathrm{h})$

$=($ Autonomy days $\times$ weighted average load work time $) / \mathrm{DOD}$

$$
=(3 \times 2.92) / 0.8=10.95 \mathrm{~h}
$$

Battery Capacity Calculation Formula:

$$
\begin{aligned}
\mathrm{CAP} & =(\mathrm{D} \times \mathrm{L})(\mathrm{DOD} \times \eta \text { out } \times \mathrm{V}) \\
& =(3 \times 17.95 \mathrm{~kW} \cdot \mathrm{h}) /(0.8 \times 0.9 \times 48 \mathrm{~V}) \approx 1558 \mathrm{Ah}
\end{aligned}
$$

CAP: Battery Capacity, Ah;

D: Autonomy days;

L: Daily electricity consumption, $\mathrm{kW} \cdot \mathrm{h}$;

$\eta$ out: Total efficiency; Take inverter efficiency for 0.92 and charge controller for 0.98 . So $\eta$ out $=0.92 \times 0.98$ $=0.9$.

\subsection{Battery Number}

In parallel: $1558 / 130=12$

In series: $48 / 12=4$

Total: $12 \times 4=48$

We choose TYPE: J150, 12 VOLT, 5-Hr Rate CAPACITY 120 Ah, 20-Hr Rate CAPACITY 150 Ah. Take 130 Ah [6].

Step 4. PV Array Sizing:

\begin{tabular}{|c|c|c|c|c|c|c|}
\hline Load Type & Numbers & Voltage & Current & Power & Service Time (h/day) & /wh \\
\hline Computer & 20 & 110 & 2 & 4400 & 3 & 13,200 \\
\hline Monitor & 20 & 110 & 0.5 & 1100 & 3 & 3300 \\
\hline Copier Fax & 3 & 110 & 8.8 & 2904 & 1 & 2904 \\
\hline Ceiling Fans & 12 & 110 & 0.7 & 924 & 6 & 5544 \\
\hline Refrigerator & 1 & 110 & 2 & 220 & 10 & 2200 \\
\hline Lighting & $3 * 6$ & 110 & 0.35 & 693 & 4 & 2772 \\
\hline Total Power & \multicolumn{4}{|c|}{$10,241 \mathrm{w}$} & Total Energy & 29,920 \\
\hline $\begin{array}{c}\text { Simultaneously Usage Rate } \\
0.6\end{array}$ & \multicolumn{4}{|c|}{$6144.6 \mathrm{w}$} & & 17,950 \\
\hline
\end{tabular}

Choose SW 225 mono of SOLARWORLD Co. which temperature character is shown in Figure 3.

Current Output Calculation [7].

\section{Table 1. Load estimate table.}




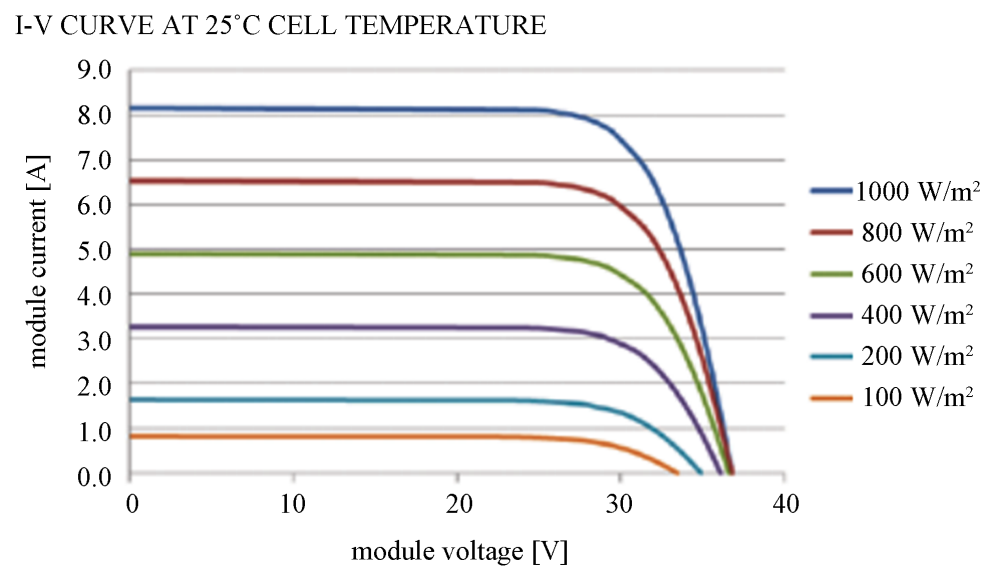

Figure 3. PV panel I-V curve.

PV Array Output Current I $=\mathrm{L} /(\mathrm{V} \times \eta 1 \times \eta 2 \times \mathrm{h})=17.95 \mathrm{~kW} \cdot \mathrm{h} /(48 \mathrm{~V} \times 0.9 \times 0.7 \times 4.8 \mathrm{~h}) \approx 123.6$

$\mathrm{L}$ : Daily electricity consumption, $\mathrm{kW} \cdot \mathrm{h}$;

$\eta 1$ : Line Loss, 0.9;

$\eta 2$ : Battery Discharge efficiency, 0.7;

h: Average sunshine hours, h; [8]

According to this current, PV panels in parallel should be 123.6/8.17 $=15.13 \approx 15$.

Number in series $=$ System Voltage/panel voltage

$=48 \mathrm{~V} / 29.7 \mathrm{~V}=1.61 \approx 2$.

PV Array power output calculation:

$$
\begin{aligned}
\text { Output } & =\text { Daily electricity consumption/Minimum sunshine time } \\
& =(17.95 \mathrm{~kW} \cdot \mathrm{h}) / 4.8 \mathrm{~h} \approx 3.73 \mathrm{Kw}
\end{aligned}
$$

Surplus capacity: $10 \%$ - 20\%, take 0.15

Battery efficiency: 0.9

Temperature loss factor: 0.9

Dust loss factor: 0.9

Controller efficiency: 0.85

$$
\begin{aligned}
\text { Safe factor }= & (1+\text { Surplus capacity }) /(\text { Battery efficiency } \times \text { Temperature } \\
& \text { loss factor } \times \text { Dust loss factor } \times \text { Controller efficiency }) \\
= & (1+0.15) /(0.9 \times 0.9 \times 0.9 \times 0.85)=1.85
\end{aligned}
$$

Output $*$ Safe factor $=3.1 * 1.77=6.92 \mathrm{~W}$

According to this output, temporarily design PV array capacity: $6.92 \mathrm{~kW}>6.14 \mathrm{~kW}$

PV Array series-parallel design

$$
\begin{aligned}
\text { Total Numbers } & =\text { PV Array power output/Maximum power for each panel } \\
& =7 \mathrm{~kW} / 225 \mathrm{~W}=30.7 \approx 30
\end{aligned}
$$

\subsection{Verification}

Numbers in parallel

$=$ daily electricity consumption $/($ columbic efficiency $\times$ paneloutput $\times$ attenuation factor $)$

$=(17.95 \mathrm{~kW} \cdot \mathrm{h} / 48 \mathrm{~V}) /[0.9 \times(225 \mathrm{~W} \times 5.79 \mathrm{~h} / 36.8 \mathrm{~V}) \times 0.9]$

$\approx 373.95 \mathrm{~A} \cdot \mathrm{h} / 28.67 \mathrm{~A} \cdot \mathrm{h} \approx 11.7<15$ 
Numbers in series and parallel are according to system voltage and current [10]. We assumed for this 6.92 $\mathrm{kWp}$ system, using 30 bucks of $225 \mathrm{Wp} \cdot \mathrm{PV}$ panels which 15 in parallel and 2 for series, system open circuit voltage is $110.4 \mathrm{~V}$; short circuit current is $81.7 \mathrm{~A}$; operating voltage $88.5 \mathrm{~V}$, operating current is $76.3 \mathrm{~A}$.

But as the actual working temperature (about $60^{\circ} \mathrm{C}$ ) rise will lead the MPPT voltage decrease, the coefficient is $-0.43 \% /{ }^{\circ} \mathrm{C}(-16.6 \mathrm{~V})$; meanwhile, in low irradiance circumstances the operating voltage would decrease too, normally down to $92 \%(-9 \mathrm{~V})$; in addition, in the wire and the connections between appliances there are voltage drops about $1 \mathrm{~V}$, so actual operating voltage is close to the charging voltage for battery, which is about $60 \mathrm{~V}$.

Charging current is about $76 \mathrm{~A}$ (Which is smaller than Constant voltage charging current limiting value: $10 \% \mathrm{C}=155 \mathrm{~A}$ ), as an ideal charging setting.

1) Battery bank and PV array design verification

Battery daily discharge rate $=$ daily load/battery capacity $=((17.95 \mathrm{~kW} \cdot \mathrm{h} / 48 \mathrm{~V}) / 1558 \mathrm{Ah} \approx 0.24<0.8$ (DOD)

So the battery bank would not over discharge;

2) Maximum charging rate $=$ Battery capacity $/ \mathrm{PV}$ Array current $=1558 \mathrm{Ah} /(7.63 \mathrm{~A} \times 10) \approx 20.4 \mathrm{~h}>10.25 \mathrm{~h}$

(Maximum charging current: $10 \% \mathrm{C}=155 \mathrm{~A}$ )

PV array would not overcharge the battery;

Step 5. Spacing between rows [11]

Take the worst situation of the year for calculation that is in December the solar angle is $47^{\circ}$ at noon when the sun is the highest in the sky using Figure 4 to illustrate.

$\mathrm{D}_{1}=\mathrm{X} \cdot \operatorname{COS} \beta=1675 \mathrm{~mm} \times \operatorname{COS} 20^{\circ}=1574 \mathrm{~mm}$

$\mathrm{H}=\mathrm{X} \cdot \mathrm{SIN} \beta=1675 \mathrm{~mm} \times \operatorname{SIN} 20^{\circ}=573 \mathrm{~mm}$

$\mathrm{D}_{2}=\mathrm{H} \cdot \mathrm{TAN}\left(\delta_{\mathrm{m}}+\mathrm{L}\right)=573 \times 2.36=1352 \mathrm{~mm}$

$\mathrm{D}_{\mathrm{T}}=\mathrm{D}_{1}+\mathrm{D}_{2}=2926 \mathrm{~mm}$

With $\delta_{\mathrm{m}}=47^{\circ}$ indicates the declination at the winter solstice (December 21), that is the time when the sun is at the lowest elevation and $\mathrm{L}$ is the latitude of the site which is $19.5^{\circ}$. In order to account for times before and after noon when the sun's angle is lower, a common distance greater should be used. It was decided that a spacing of $3000 \mathrm{~mm}$ would be acceptable and the whole frame work is shown in Figure 5.

Step 6. Inverter and Charge Controller: [14]

According to Solar world website. Solar World makes good use of the longstanding experience of SMA, the German market leader with respect to efficiency, durability, cost effectiveness and service.

Solar World solar power systems are optimally enhanced by SMA inverters. The SMA inverters are a perfect fit for Solar World's definition of quality.

Solar World uses Inverters (besides SMA) and Charge Controllers of STECA, a leading supplier for regulation and control of solar energy systems. Its long lasting experience, high quality standards and cost effectiveness match to Solar World's demands primarily for off-grid systems [15].

Inverter capacity $=$ Load Power $/ 0.8=6144 \mathrm{~W} / 0.8=7.68 \mathrm{~W}$

In this system we use SMARTFORMER FOR SUNNY ISLAND inverter.

Controller current $=$ System capacity/voltage $*$ loss factor $=6.92 \mathrm{KW} / 48 * 0.85=122.4 \mathrm{~A}$

For charge controller we use Steca Tarom 4140 [16].

\section{Power System Simulation and Performance Result}

Simulation by PVsyst [17] is presented in Figure 6.

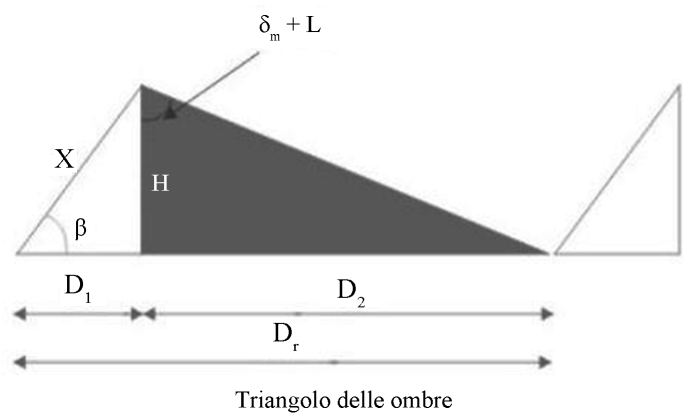

Figure 4. Distance between the rows of panels. 


\section{Market Analysis}

\subsection{Estimation Cost}

1. System Investment Content

This PV system has installed capacity of $6.92 \mathrm{~kW}$, investment include PV panels, off-grid inverter, batteries, charge controller, AC circuit breaker, wires, PV panel mounting rack, power shed, labor fees and so on which are presented in Table 2 and Table 3.

2. Project budget

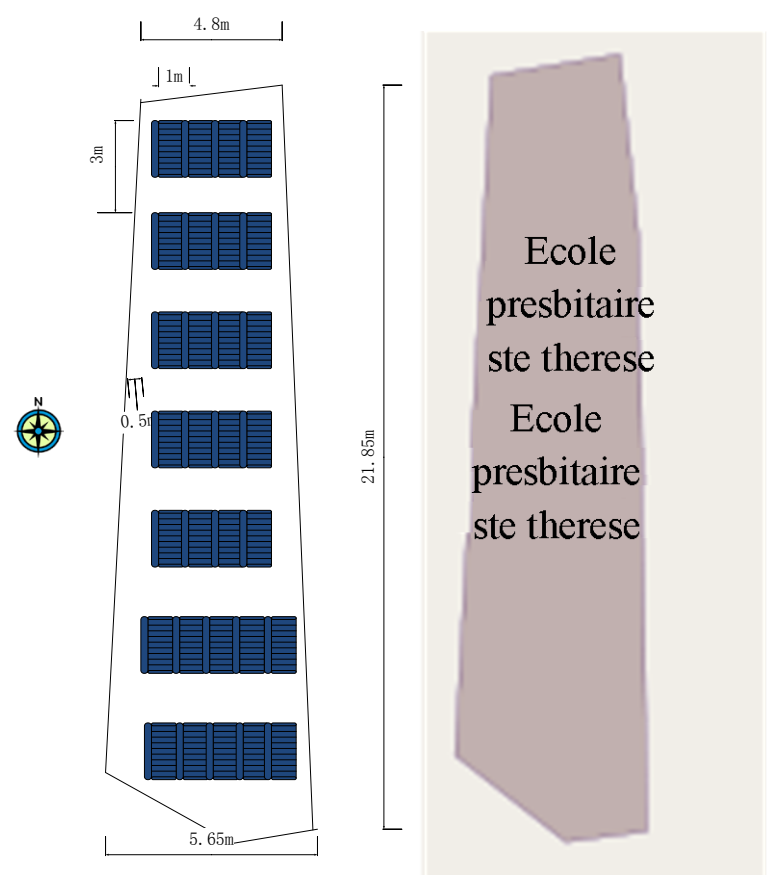

Figure 5. PV panels layout [9].

Table 2. Project contents.

\begin{tabular}{cccccc}
\hline$\#$ & Title & Supplier & Standard & Amount & Unit Price \\
\hline 1 & PV Panels & Solarworld & SW 225 & 24 & 350 \\
2 & Inverter & SMA & SMARTFORMER & 1 & 1800 \\
3 & Controller & Steca & POWER TAROM 4140 & 1 & 2000 \\
4 & Batteries & Trojan & J150 & & 220 \\
5 & Mounting & Self-collect & & & \\
6 & Breaker & Self-collect & Self-collect & & \\
7 & Wires & & &
\end{tabular}

Table 3. Project cost.

Wood or metallic frame installation

Batteries

PV panels

Inverter

Controller
$\$ 2.5 \times 225 \times 30=16,875 \$$

$\$ 220 \times 48=10,560 \$$

$\$ 350 \times 30=10,500 \$$

$\$ 1800$ 


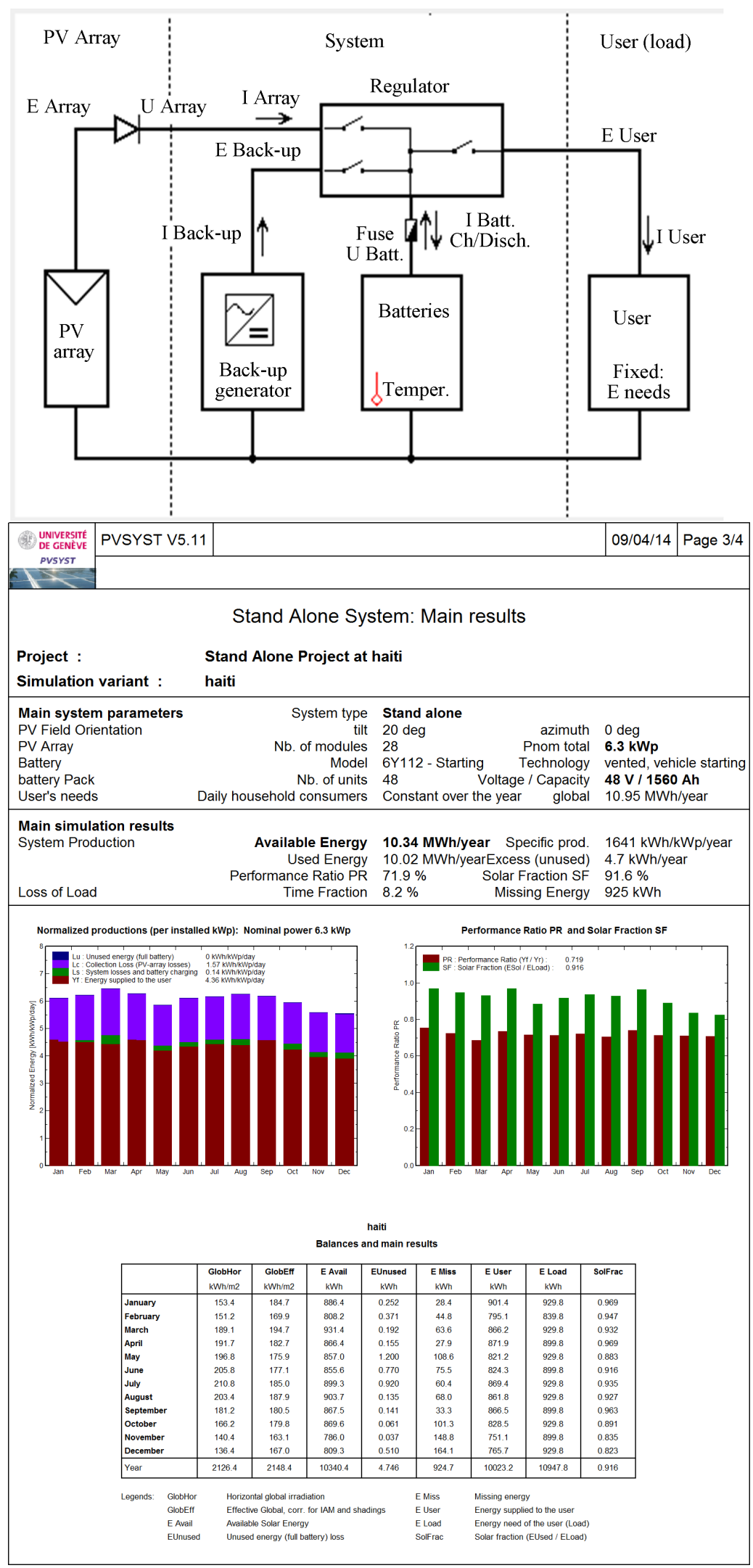

Figure 6. Simulation result. 
According to the latest edition of Tracking the Sun, an annual PV cost tracking report produced by the Department of Energy's Lawrence Berkeley National Laboratory (Berkeley Lab). The report indicates that the median installed price of PV systems completed in 2012 was $\$ 5.30 / \mathrm{W}$ for residential and small commercial systems smaller than 10 kilowatts $(\mathrm{kW})$ in size. It fell by $0.90 \$$ per Watt in 2013. For developing country the labor is cheaper, take India for reference, its rate is around $2.5 \$$ per Watt for installation [18].

$$
\text { Total }=16,875+10,560+10,500+1800+2000=41,732 \$
$$

All of these cost items are variable costs, so the cost will increases with total installed capacity and if there is expansion in the future.

\subsection{Assumptions}

1) The total installed capacity of $6.92 \mathrm{kWp}$, the total cost is $41,735 \$$;

2) The project is completed in 2014 (from the proposal been accepted);

3) The total investment donated is tentatively scheduled for $70 \%$;

4) Through simulation software estimation, the first year of the project the system will generate about 14,712 $\mathrm{kW} \cdot \mathrm{h}$ in total, take the annually decay rate by eight thousandth, within 25 years of life cycle the total generation is $334,563.4 \mathrm{~kW} \cdot \mathrm{h}$, plus a roughly annual cost of $\$ 3325$ for maintenance, the average price is about $0.35 \$$ / $\mathrm{kW} \cdot \mathrm{h}$.

The payback period is easy to get then by following. As we know in Haiti the cost of electricity produced by the electric grid company is about $0.23 \$ \mathrm{~kW} \cdot \mathrm{h}$, and take the first year production which will lead to $\$ 3383$ value. So the payback time of this system is 10.71 year, compared to the average payback time for the developing countries, which is 6.76 years.

\section{Conclusions}

This Photovoltaic system is designed for SOLARWORLD donated Haiti school project. The off-grid PV system can produce total energy of $14,000 \mathrm{~kW} \cdot \mathrm{h}$ per year with total cost of $\$ 41,735$ dollars.

Without electricity and distribution system has been erected in remote regional, independent photovoltaic system become a very effective application which has broad prospects. When designing of a stand-alone PV system, PV array and the battery capacity is the basic design. In this thesis, through studying examples of standalone PV systems, the stand-alone PV system design steps are summarized as well as solve the real problem. In addition, discusses the independent photovoltaic Array design and battery capacity calculation problem. For the capacity design, besides load cases, fully consideration about the environmental conditions is very important: include the site location, solar radiation, climate, topography and surface features and so on. Summarized steps can be used for other stand-alone PV system design.

\section{References}

[1] Solar Energy International, "Photovoltaic Design and Installation Manual”. September 1, 2004.

[2] EME 580. Design and Simulation of a Distributed PV System for Pennsylvania State University. May 3, 2010.

[3] NASA Surface Meteorology and Solar Energy, Atmospheric Data Center. https://eosweb.larc.nasa.gov/

[4] Linuo Solar Power, "Solar power system design” Feburary, 2010.

[5] Mellon, “5Kwp Off-grid PV system Design”. November 12, 2013.

[6] Trojan Battery “J150 Data Sheet”. http://www.trojanbatteryre.com/PDF/datasheets/J150_TrojanRE_Data_Sheets.pdf

[7] Solarworld Sunmodule "SW225 Poly Data Sheet". http://www.solarworld-usa.com/ /media/www/files/datasheets/sunmodule-poly/sunmodule-solar-panel-225-poly-ds.pd $\underline{\mathrm{f}}$

[8] Salameh, M.Z. Fundamentals and applications of Photovoltaic. University of Massachusetts Lowell, MA.

[9] Panhathai Buasri, “Ahybrid Wind/Photovoltaic System Design for the Lowell National Historic Park Maintenance Shop”. June 28, 2001.

[10] Göteborg, Sweden 2011, JONAS BARMAN, “Design and feasibility study of PV systems in Kenya”.

[11] Hussam, S.M. (2004) Design and Implementation of a Solar Power System in Rural Haiti. February, 2011.

[12] “School Top View”, Open Street Map. 
http://www.openstreetmap.org/search?query = st\%20margaret\%20mary\%20haiti\#map =15/19.7508/-72.4248

[13] “School Location”, Google Map.

https://www.google.com/maps/dir/19.7501562,-72.428484/Port-Margot,+\%E6\%B5\%B7\%E5\%9C\%B0/@19.7456437, -72.4245395,22062m/data=!3m1!1e3!4m8!4m7!1m0!1m5!1m1!1s0x8eb6ec0b194aeaa1:0xd8d84c58ffb05805!2m2!1d -72.4295132 !2d19.7517168?hl=zh-CN

[14] Sungrow Co. “Off-grid photovoltaic power generation system”. Noverber, 2011.

[15] SMA Sunny Island "Smart Battery Inverter Data Sheet”. http://www.sma.de/en/products/off-grid-inverters/smartformer-for-sunny-island.html

[16] Steca Power Tarom “Charge Controller 4140 Data Sheet”. http://www.steca.com/index.php?Steca_Power_Tarom_en

[17] PVSyst Software Basic Tutorial. http://bbs.21spv.com/thread-38739-1-1.html

[18] Installed Price of Solar Photovoltaic Systems in the US. Lawrence Berkeley. http://newscenter.lbl.gov/news-releases/2013/08/12/installed-price-of-solar-photovoltaic-systems-in-the-u-s-continues-t o-decline-at-a-rapid-pace/ 
Scientific Research Publishing (SCIRP) is one of the largest Open Access journal publishers. It is currently publishing more than 200 open access, online, peer-reviewed journals covering a wide range of academic disciplines. SCIRP serves the worldwide academic communities and contributes to the progress and application of science with its publication.

Other selected journals from SCIRP are listed as below. Submit your manuscript to us via either submit@scirp.org or Online Submission Portal.
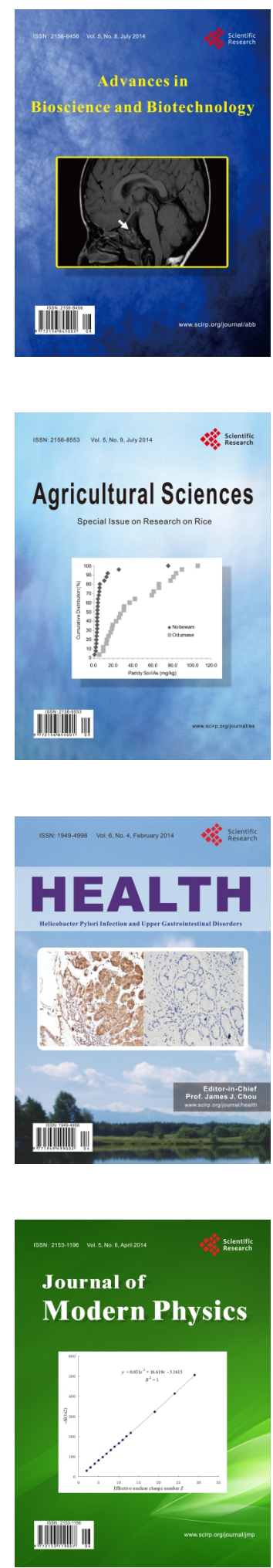
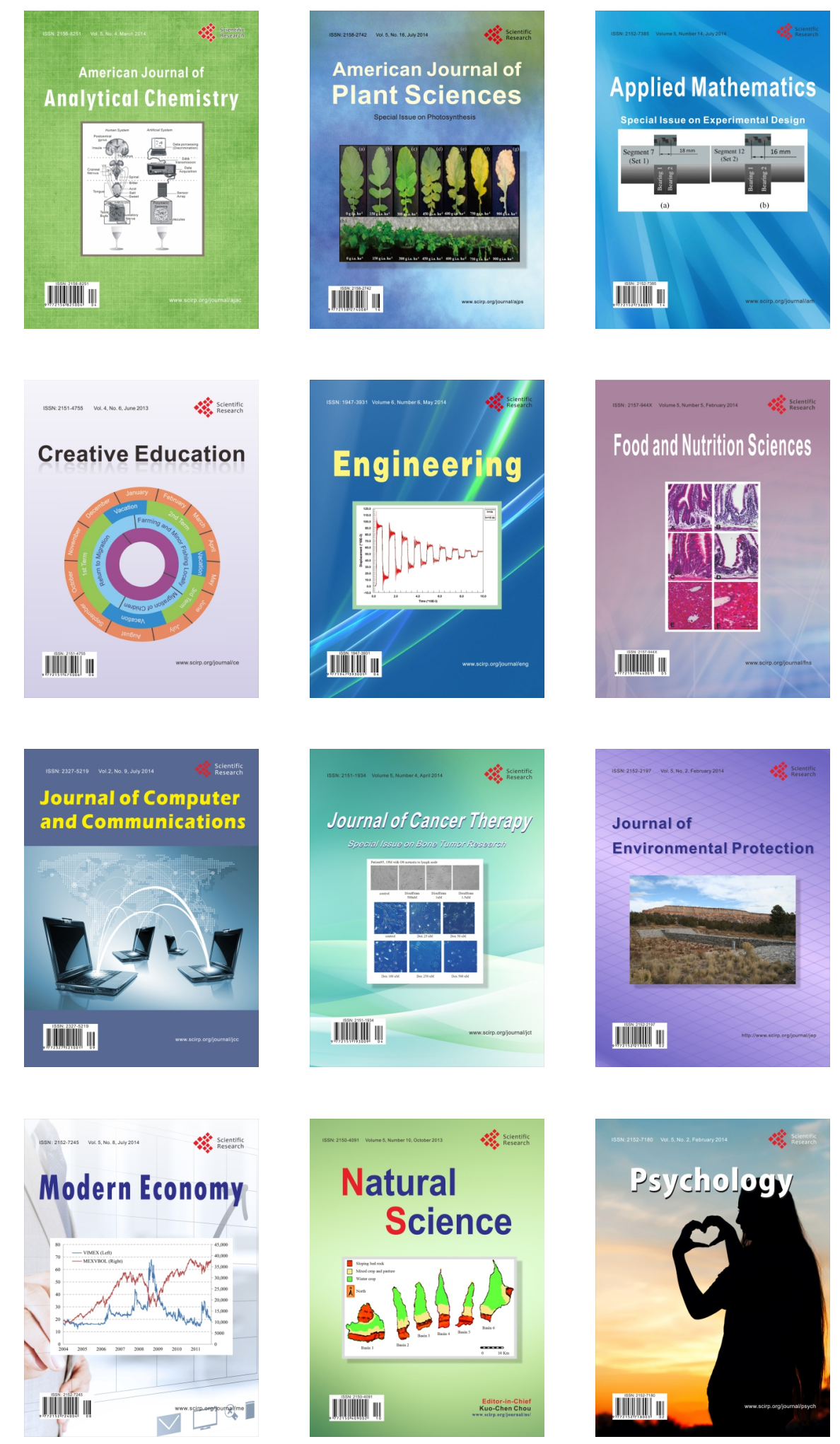